\title{
The development of thin thrust sheets and basement- cover sandwiches in the southern part of the Rinkian belt, Umanak district, West Greenland
}

\author{
T. C. R. Pulvertaft
}

\begin{abstract}
At the southern margin of the Rinkian belt, West Greenland, it can be demonstrated that the Lower Proterozoic Marmorilik Marble Formation, which was deposited unconformably on a gneiss basement, has been squeezed and stretched into a thin recumbent syncline and overridden by the basement over an area of more than $1000 \mathrm{~km}^{2}$. A second supracrustal cover unit, seen now as a thin mylonitic biotite schist horizon, occurs at a slightly higher structural level, and marks the site of another thrust along which the gneiss basement has overridden its supracrustal cover.

The demonstration that a superficially simple sequence consisting of concordant layers of different gneiss types and supracrustal rocks is in fact a pile of thrust sheets, has important implications for the interpretation of both West Greenland and other Precambrian areas.
\end{abstract}

\section{Introduction}

The Geological Survey of Greenland (GGU) began systematic investigations in the Umanak district, West Greenland, when the late G. Henderson and the present writer mapped the three 1:100 000 sheets in the northern part of the district in 1962 and 1963. That it was possible to issue three 1:100 000 sheets on the basis of only two seasons' field work by two geologists was due to three factors: (1) magnificent exposure in steep, bare mountain sides; (2) the large, relatively homogeneous character of the mappable formations which are easy to distinguish from one another in the field and on aerial photographs; (3) the complete integration of field work and photogeology, together with Gilroy Henderson's skill and patience as a photogeologist.

Encouraged by the success of photogeological interpretation accompanied by limited field work in the three northern sheet areas, the writer attempted to complete the Agpat sheet, the southernmost sheet in the Umanak area, on the basis of a single season's field work in 1965. However, in this part of the Umanak area there are no major units that can be identified easily on aerial photographs and mapped from a distance, so a single season's field work by one geologist was not enough for preparation of a 1:100 000 sheet. On the other hand, much of the terrain in the Agpat sheet is more accessible than the alpine areas to the north and more amenable to conventional mapping, so when the opportunity arose for GGU to support a larger party in the area, it was agreed that the writer together with four senior students from the University of Copenhagen and Dr J. Grocott, University of Amsterdam, should complete the mapping of the Agpat sheet employing much the same logistic approach as that used in southern West Greenland. In all, 12 man-seasons were spent in the sheet area in the years $1978-80$. 


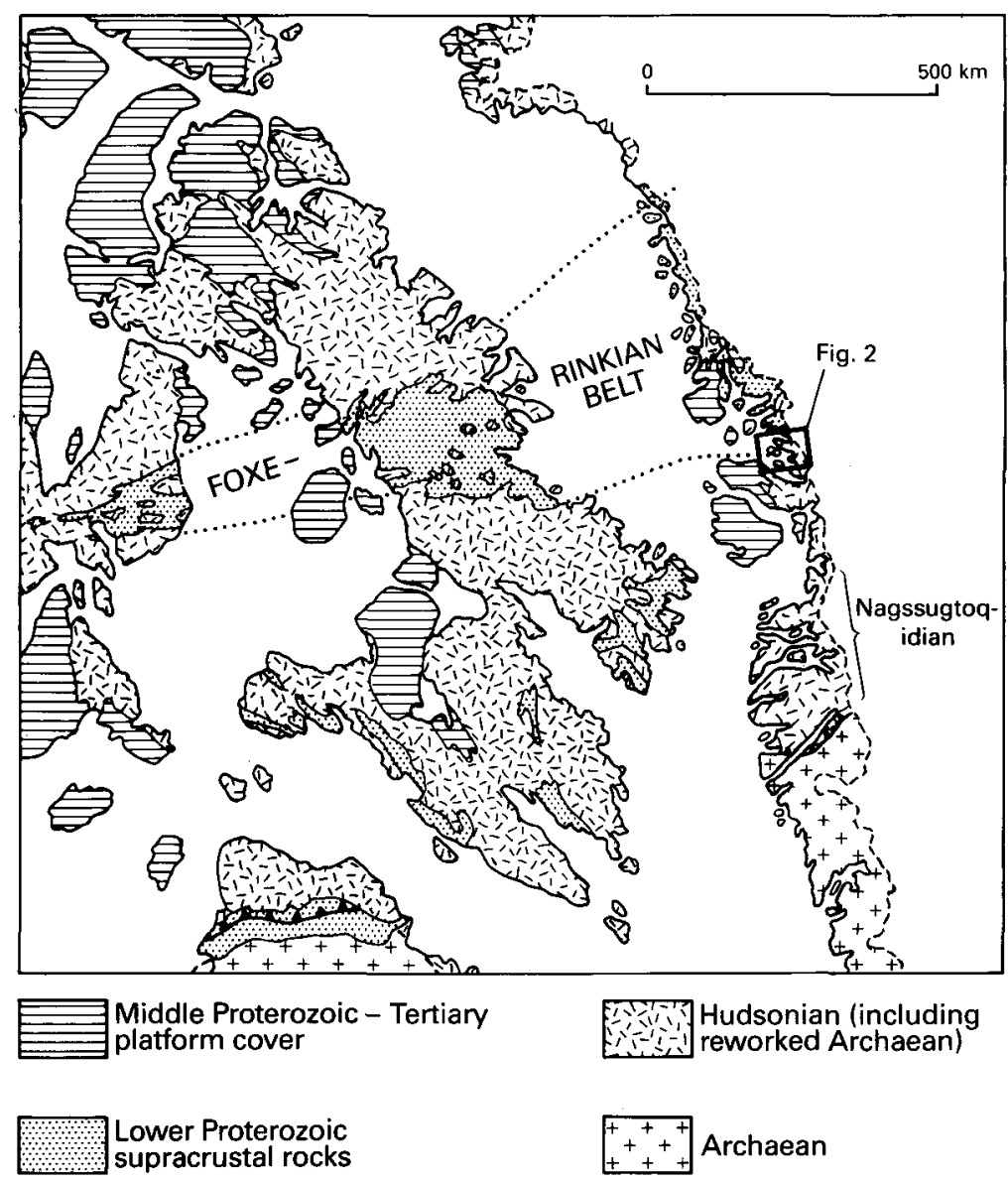

Fig. 1. Map showing the position of the area shown in fig. 2 relative to the Foxe-Rinkian and Nagssugtoqidian belts. The pre-drift fit is a compromise between many different proposals, designed to reduce the lateral displacement and gap in Nares Strait to a minimum (cf. Dawes \& Kerr, 1982).

The geological results of the 1962, '63, and ' 65 seasons were summarised by Escher \& Pulvertaft (1976). The purpose of the present paper is to present some of the newer results, not only from the 1978-80 seasons but also of work done in the Mârmorilik area in the mid-70s, results that require a modification of the picture of the Rinkian given by Escher $\&$ Pulvertaft (1976). The position of the area with which the paper is concerned is shown in fig. 1.

\section{Summary of previous work}

The main elements in the Precambrian in the northern part of the Umanak area are (1) an Archaean gneissic basement, and (2) the Karrat Group, a Lower Proterozoic supracrustal cover consisting of two formations, the Qeqertarssuaq Formation (lower) and the Nukavsak Formation. The Qeqertarssuaq Formation varies in thickness from less than $25 \mathrm{~m}$ to more 
than $2 \mathrm{~km}$. It consists of quartzite, mica schists often containing garnet, staurolite and sillimanite, a little amphibolite, and locally a thin marble horizon. At the top of the formation there is a marker horizon of amphibolite or hornblende schist that is continuous over the entire extent of the formation, even where it is thinnest. The contact between this horizon and the overlying Nukavsak Formation is easy to see, even at a great distance. The Nukavsak Formation is a typical flysch formation. It is up to at least $4.5 \mathrm{~km}$ thick and consists almost entirely of alternating layers of metagreywacke and pelitic schist. The monotony of the formation is occasionally relieved by horizons of rusty-weathering graphite-pyrrhotite schist.

The structural contour map of the base of the Nukavsak Formation shows a relatively simple pattern of domes (Henderson, 1969), except in the south-west where a large recumbent fold or nappe - the Kigarsima nappe - has brought a core of gneiss from the south-west in over the Nukavsak Formation. In contrast, structures within the Nukavsak Formation are complex; early tight zig-zag folds are refolded by large overturned folds with axes and vergence apparently governed by the domes. The folds within the Nukavsak Formation are regarded as having been formed by gravity gliding towards depressions between the domes.

Also in the gneiss below there is a more complicated structural pattern than that revealed by the base of the Nukavsak Formation, a number of recumbent folds occurring not far below the base of the supracrustals. It was therefore thought at first (Henderson \& Pulvertaft, 1967) that these structures must have developed in the basement before the deposition of the overlying Karrat Group, but this view was revised (Pulvertaft, 1973) when it was realised that ultrabasic-basic intrusions, apparently intruded after the deposition of the Qeqertarssuaq Formation, are folded by recumbent folds in the gneiss and boudinaged by stretching.

In the southern part of the Umanak area there is another major supracrustal unit, the Marmorilik Formation. This is a more than $2 \mathrm{~km}$ thick carbonate formation dominated by dolomite and calcite marbles, but at the base there is a clastic unit consisting of fine-grained semipelite, graphitic pelite and psammite, and glassy quartzite with cross-bedding and wave ripple marks (Garde, 1978). Henderson \& Pulvertaft (1967) regarded the Marmorilik Formation as belonging to the basement to the Karrat Group, partly because it is completely separated geographically from this group, and partly because it is folded in large recumbent folds that they believed could not have developed after the deposition of the Nukavsak Formation, given the simple structural style revealed by the contour map of the base of this formation. However, later work (Garde \& Pulvertaft, 1976) in areas of low deformation revealed beyond any doubt that the Marmorilik Formation was deposited with angular unconformity on the Umanak gneisses, and the formation is now regarded as the lateral equivalent of the Qeqertarssuaq Formation. This revised view on the stratigraphic position of the Marmorilik Formation is of great importance to the interpretation of the structures in the Agpat sheet area.

Isotopic dating (Rb-Sr whole-rock isochrons - Kalsbeek, 1981; Andersen \& Pulvertaft, 1985) has shown that the basement on which the Marmorilik Formation was deposited is at least $2500 \mathrm{Ma}$ old, while regional metamorphism in the Marmorilik Formation terminated about $1700 \mathrm{Ma}$ ago.

\section{Primary relations between the Marmorilik Formation and its basement}

Before the effects of deformation are described, it is necessary to describe briefly the primary relations between the Marmorilik Formation and the granitoid-gneissic basement. The 


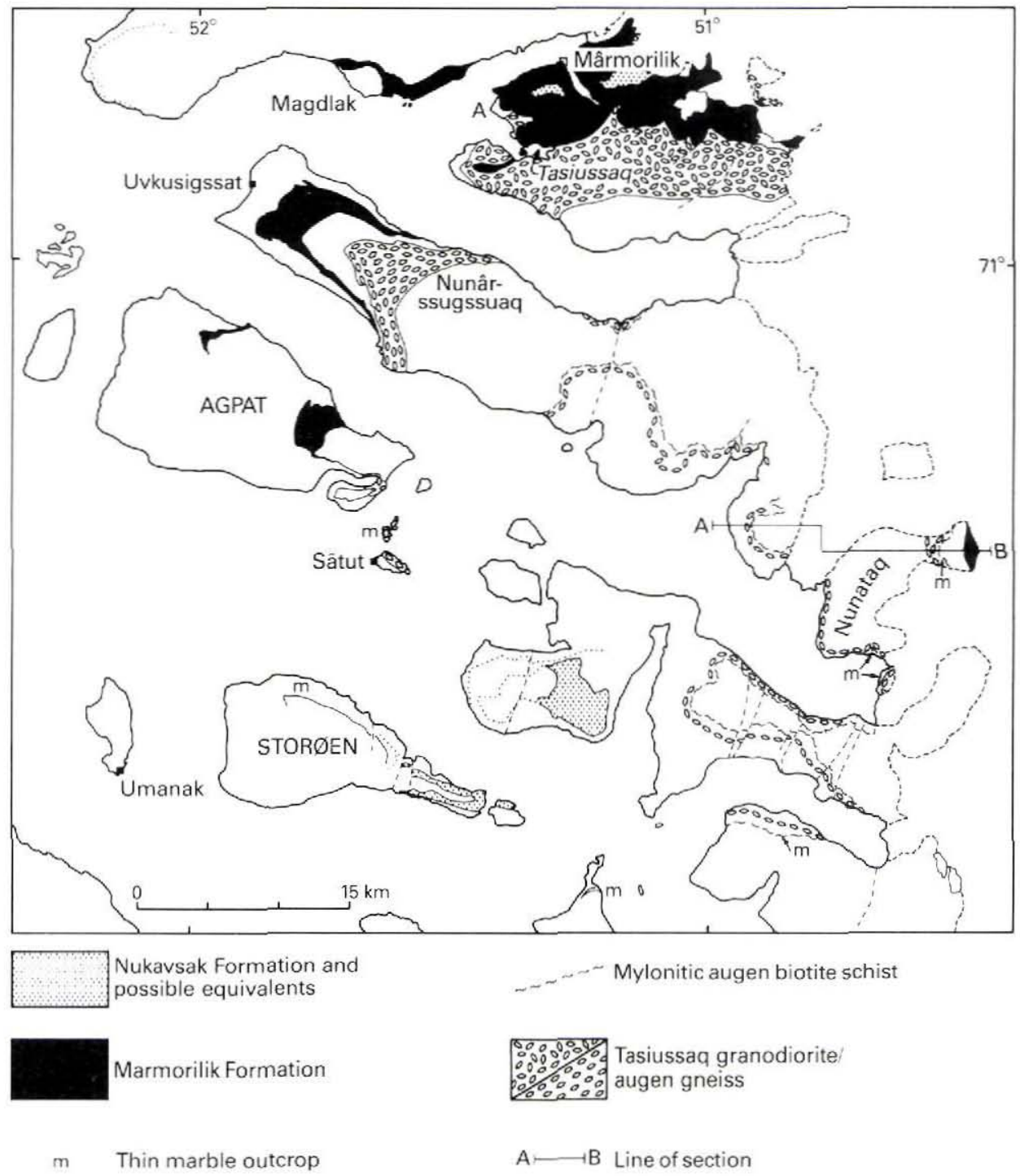

A

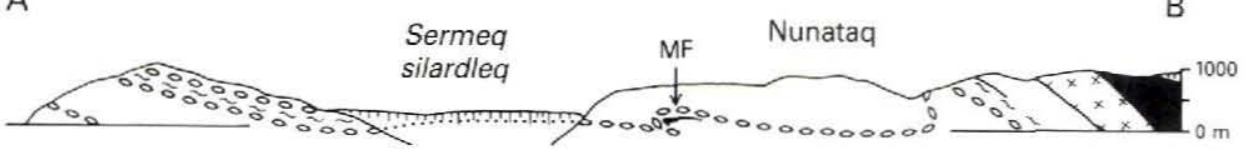

Marmorilik Formation

$\sim$ Mylonitic schist
$+{ }_{+}^{+}$Akuliarusikavsak tonalite gneiss

00 Augen gneiss

Fig. 2. Map of the marker horizons described in the text, and a representative cross-section of part of the area. Note that the uppermost augen gneiss horizon shown in the cross-section has been omitted from the map because it cannot be proved to belong to the Tasiussaq augen gneiss. A: Akuliarusikavsak. 


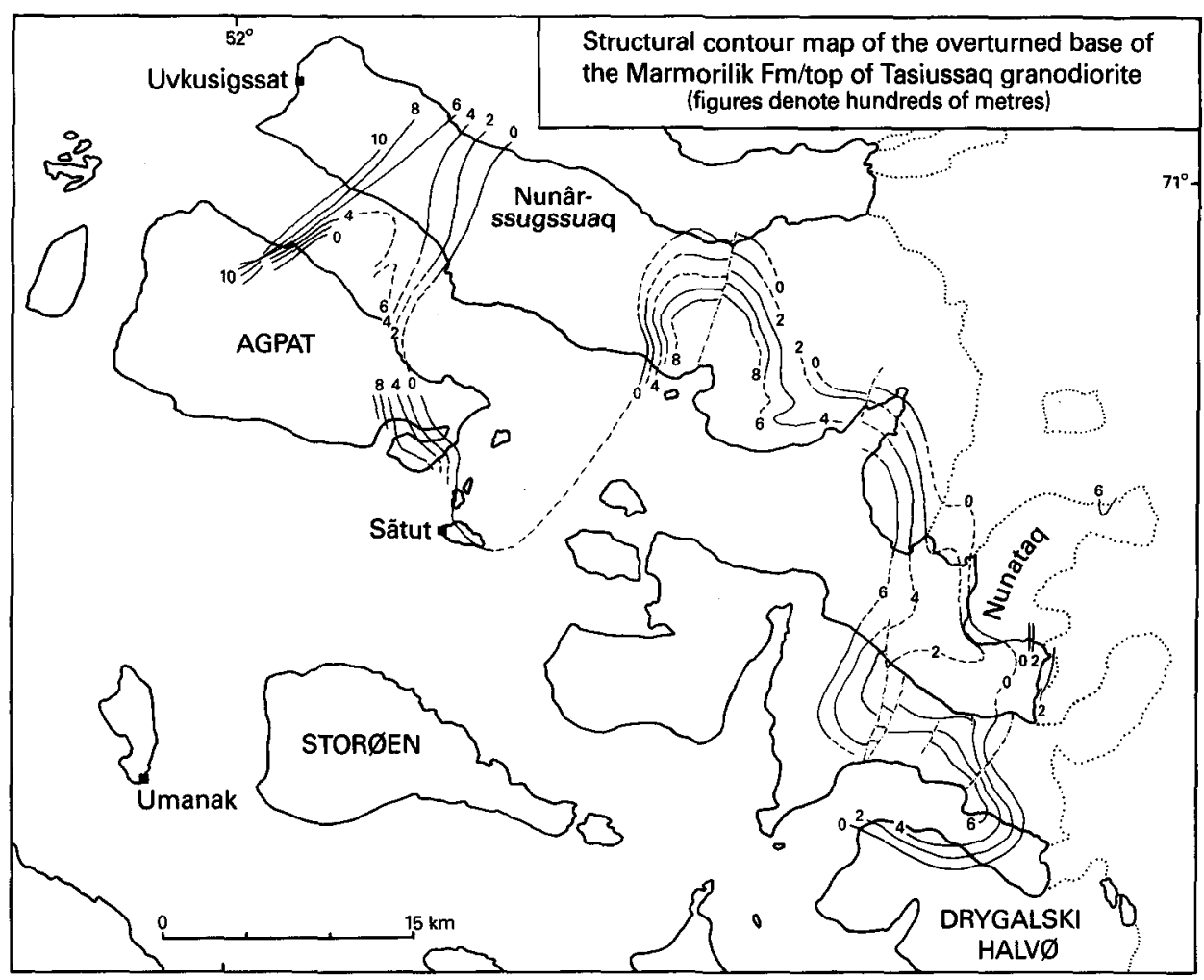

Fig. 3. Structural contour map of the lower surface of the Tasiussaq augen gneiss and, in north-west Nunârssugssuaq and Agpat, of the inverted base of the Marmorilik Formation. Compare with fig. 2.

primary relations are best seen south-east of Mârmorilik, at Magdlak $15 \mathrm{~km}$ west of Mârmorilik, and at the inner end of Nunataq (fig. 2. Note that 'Nunataq' is a place name; the name is quite specific enough for the local population who have no need to distinguish their local nunatak from other nunataks farther away!).

South-east of Mârmorilik, the Marmorilik Formation lies in a simple ESE-WNW syncline in the basement (Garde, 1978). The internal structure of the formation is complicated by overturned and recumbent folds, but the effects of these are mostly restricted to within single members in the formation so that the basal unit and its contact with the basement remain unaffected and define a simple structure. Everywhere where the contact is exposed, basal orthoquartzite lies on sheared, coarse biotite-hornblende-sphene granodiorite with feldspar megacrysts. This rock, for convenience referred to as the Tasiussaq granodiorite/augen gneiss, has yielded an Rb-Sr isochron age of $2570 \pm 90$ Ma (Kalsbeek, 1981).

North-east of Mârmorilik, the basal contact of the Marmorilik Formation is not exposed. The gneiss closest to ( $250 \mathrm{~m}$ from) the formation here is a distinctive medium-grained homogeneous 'small augen' tonalite gneiss. The same rock type underlies the Marmorilik Formation on the point Akuliarusikavsak south-west of Mârmorilik, and for convenience it is referred to as the Akuliarusikavsak tonalite gneiss. 
At Magdlak, the Marmorilik Formation has been folded into a complex overturned syncline. However, in spite of the structural complications, an angular unconformity between quartzite of the basal unit of the formation and the underlying heterogeneous, polyphase biotite gneiss is clearly seen on the lower flank of the syncline.

At the eastern end of Nunataq, the Marmorilik Formation lies on tonalite gneiss of Akuliarusikavsak type. The tonalite gneiss shows a well-developed foliation parallel to the eastward dipping contact of the Marmorilik Formation, and at the contact itself the gneiss is strongly sheared. The basal unit of the Marmorilik Formation is thin, or locally absent, due to movements at the contact. Discordance is seen where pegmatites in the tonalite gneiss are cut off at the base of the Marmorilik Formation.

\section{Folding and thrusting involving supracrustal cover in the southern Mârmorilik and Agpat sheet areas}

South-west of Mârmorilik, the base of the Marmorilik Formation appears from the 1:100 000 sheet Mârmorilik to be simple, with the base of the formation crossing with angular discordance the contact between the Tasiussaq megacryst granodiorite and the Akuliarusikavsak tonalite gneiss. However, field work in 1975 revealed that a thin wedge of intensely sheared Akuliarusikavsak gneiss has been driven almost parallel to the bedding into the basal unit of the Marmorilik Formation. A little to the west there are bands of mylonite up to $10 \mathrm{~cm}$ thick in the tonalite gneiss alongside the contact of the formation. A low-plunging, E-ESE trending lineation is developed in both the Marmorilik Formation rocks and the tonalite gneiss in the neighbourhood of their contact.

At Magdlak, no discordance can be seen at the upper, overturned, low-dipping contact of the Marmorilik Formation. The overlying gneiss is very strongly foliated close to the contact. A little above, both compositional and pegmatitic layering (Myers, 1978) can be seen. Very low-angle discordances between rock types show that here one is dealing with an originally veined polyphase rock mass which has been so strongly deformed by ?simple shear that boundaries between rock types are now almost perfectly parallel. A distinct $\mathrm{E}-\mathrm{W}$ lineation is developed in the flayed-out gneiss. At two places, very narrow low-dipping wedges of Marmorilik Formation have been folded into the gneiss. Although as little as $2-3 \mathrm{~m}$ thick, these can be followed up to $300 \mathrm{~m}$ from the main outcrop of the formation. In one case there is marble in the middle and basal quartzite on either side, while in the other only rocks of the basal unit have been infolded into the wedge. The gneiss on the upper side of each wedge is much more intensely sheared than that on the lower side.

These outcrops serve to illustrate on a modest scale that thin concordant layers of quartzite and marble in well-foliated gneiss can be infolded wedges of supracrustal cover.

On the mountain west-south-west of Tasiussaq, the Marmorilik Formation is folded down into the Tasiussaq granodiorite in an upright syncline.

In the outer (north-west) part of the Nunârssugssuaq peninsula, the Marmorilik Formation lies in a large-scale, tight, almost recumbent syncline with axial plane dipping about $7^{\circ}$ to the south-east. As will be apparent later, the closure of this syncline may lie as much as 50 $\mathrm{km}$ to the south-east or south-south-east. The synclinal character of the structure is, however, demonstrated by the fact that the basal unit occurs both along the lower contact and, in mirror image, along the upper contact of the formation. The Tasiussaq granodiorite, now better described as augen gneiss, occurs on the upper, overturned flank of the fold and is 


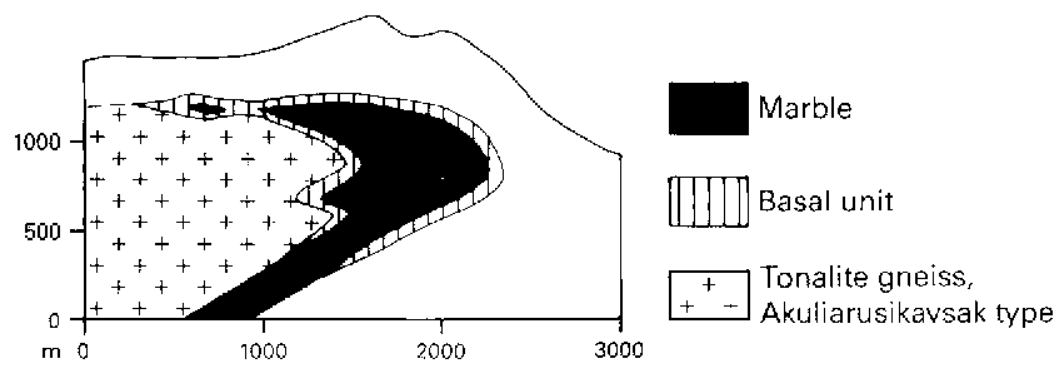

Fig. 4. Profile of the fold involving the Marmorilik Formation in north-west $\Lambda$ gpat.

separated from the Marmorilik Formation by $\mathrm{c.} 300 \mathrm{~m}$ of rather featureless gneiss. A thin amphibolite layer occurs at the lower contact of the augen gneiss.

In the cliffs at the north-western end of the peninsula there is both infolding of a narrow wedge of Marmorilik Formation into gneiss and thrusting of gneiss north-westwards over the basal unit on the lower flank of the syncline. Structures are not cylindrical, as structures seen in the north-cast and south-west facing cliffs cannot be matched.

Lack of cylindricity is even more marked when structures seen in the south-west facing cliffs of the Nunârssugssuaq peninsula are compared to those in the cliffs opposite on the north-east side of Agpat island. Here, folding of the Marmorilik Formation into the basement gneisses becomes very complicated. In the north-westernmost outcrop. the formation occurs in a refolded isoclinal syncline that closes upwards into the gneiss (tig. 4). The gneiss flanking the structure to the south-east is tonalite gneiss of Akuliarusikavsak type.

Farther to the south-east, the Marmorilik Formation reappears in a complex, relatively badly exposed and not fully understood structure, but marble can be traced with certainty through scattered outcrops to the south-east side of the island. Here, the Marmorilik Formation runs side-by-side with banded amphibolite (fig. 5). Both in lithology and field relations, this amphibolite is identical to the Archaean amphibolite horizons in the basement of the Umanak area. The Marmorilik Formation layer has rocks of the basal unit along both the upper and lower contacts. so it constitutes a very tightly squeezed isoclinal syncline. Tasiussay augen gneiss reappears here on the upper flank of the syncline. The whole sequence has been refolded in tight folds overturned to the west, and later thrusting has brought other gneiss types over the Tasiussaq augen gneiss and supracrustal rocks (fig. 5).

On the islands to the south, overturned basal clastics and marble of the Marmorilik Formation dip $15-20^{\circ}$ east under lineated and strongly sheared Tasiussaq augen gneiss. while at the west end of Satut island the formation is reduced to less than two metres of glassy quartzite, pyrrhotite-rich calc-silicate and diopsidic gneiss. At the east end of this island, the formation has disappeared altogether, and Tasiussay augen gneiss lies directly on amphibolite which in turn lies on typical country gneisses.

At the southern end of Nunatac there is an important outcrop of the Marmoritik Formaton. Ihis is situated in the closure and along the upper flank of an antiform that is overturned cowards the west (fig. 2). Although the basal quartzite is missing here, other rocks typical of the basal unit occur along both the upper and lower contacts of the formation. Overlying the outcrop there is a horizon of biotite-hornblende-sphene augen gneiss identical to the Tasiussaq augen gneiss. The situation resembles closely that on the south-east side of Ag- 


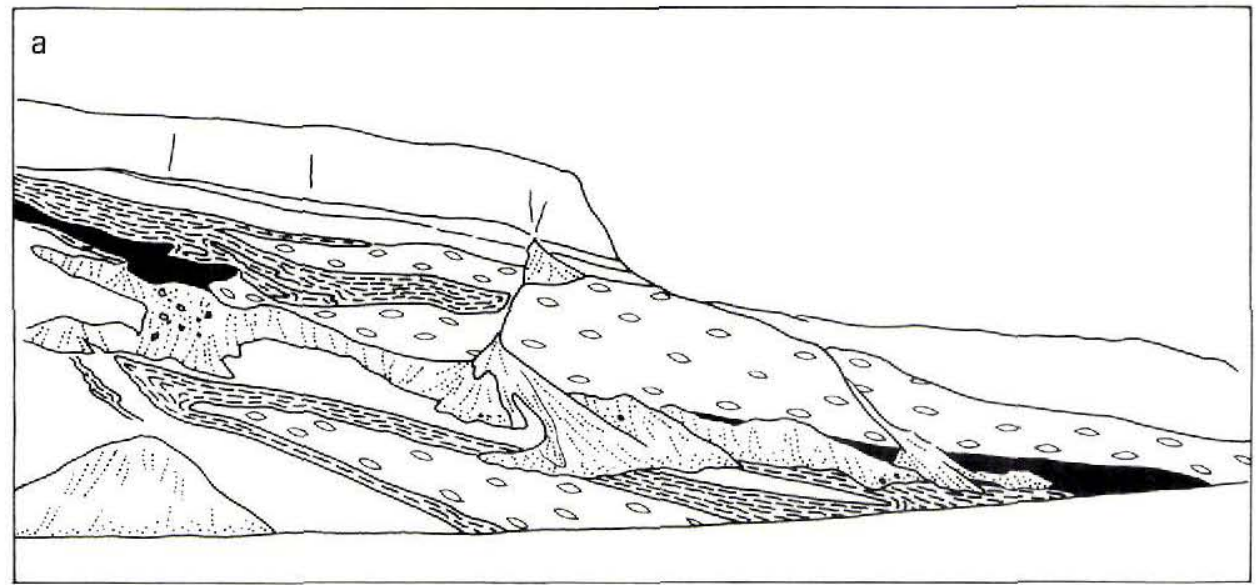

Marmorilik Formation 0 Tasiussaq augen gneiss

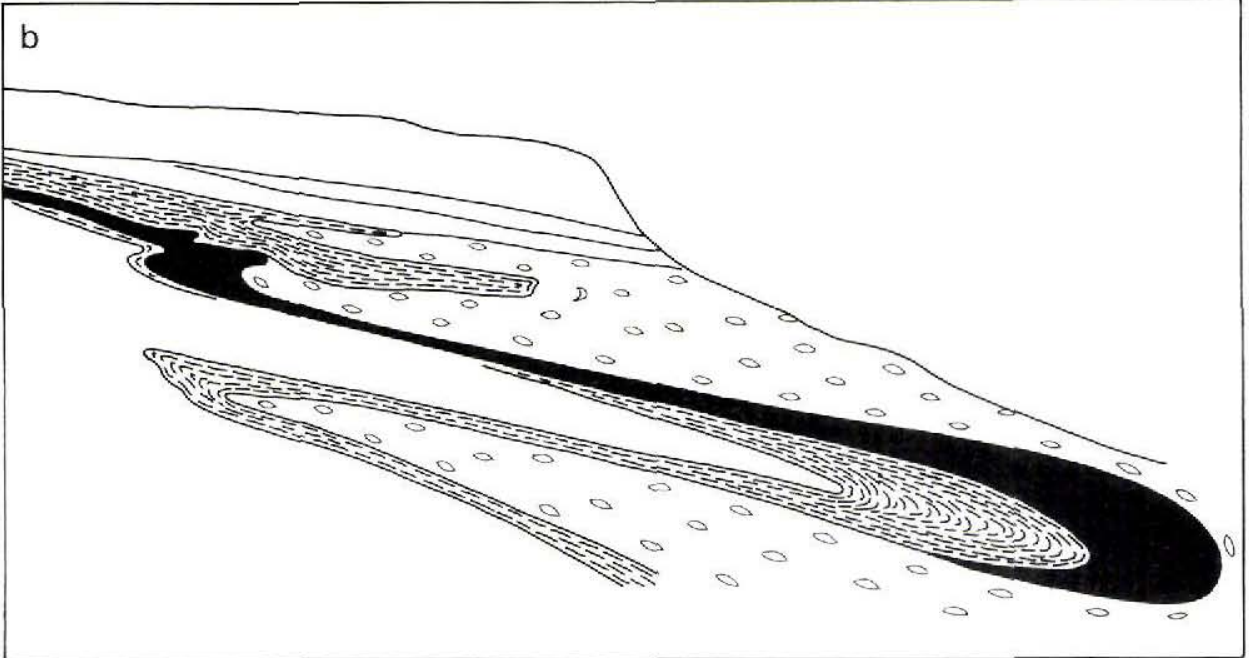

Fig. 5. (a) The south-east side of Agpat, drawn from a colour slide; (b) the structure on south-east Agpat, extrapolated from (a). Height of cliff on left $600 \mathrm{~m}$.

pat. In the south-western corner of Nunataq, the Marmorilik Formation is pinched out, and there are only discontinuous lenses of amphibolite between the Tasiussaq augen gneiss and the gneiss below.

Near the north-east end of Nunataq, augen gneiss resembling - and presumed to be - Tasiussaq augen gneiss is brought up to the erosion level by another westwards-overturned antiform. The structural position of the augen gneiss here is consistent with it being the same horizon as that exposed in the south-west of Nunataq. There is flaggy banded amphibolite 
but no marble below the augen gneiss; the gneiss immediately below the amphibolite is very highly strained and almost mylonitic.

About $200 \mathrm{~m}$ above the augen gneiss there is another, more conspicuous, marker horizon in the country gneisses. This horizon consists of rusty-weathering biotite schist, both glassy and mylonitic quartzite, and tremolite marble. Discontinuous banded amphibolite occurs along both the upper and lower contacts of the horizon. While there is no proof that this horizon consists of thinned-out Marmorilik Formation and Nukavsak Formation rocks, there are no other supracrustal rocks in the region that it resembles, least of all amongst the proven Archaean units (cf. Knudsen, 1983). Strong deformation has taken place along some levels within the horizon.

The Tasiussaq augen gneiss seen in the south-west of Nunataq continues on the west side of the glacier Sermeq silardleq, with banded amphibolite often present along its lower surface.

Two more marker horizons occur in the country gneiss above the Tasiussaq augen gneiss west of Sermeq silardleq (fig. 2). The lower of these was first called 'augen biotite schist' but in fact over much of its extent is a mylonitic biotite schist (cf. Sibson, 1977) with oval porphyroclasts of feldspar (mainly plagioclase) up to a centimetre long. It gives rise to a conspicuous step feature that is distinct on aerial photographs. This mylonitic schist horizon occupies the same structural position as the rusty-weathering schist, quartzite and marble horizon in the north-east of Nunataq, and furthermore includes occasional marble lenses and has in places thin amphibolite along both the upper and lower contacts.

The uppermost marker here is another augen gneiss horizon that is lithologically very similar to the Tasiussaq augen gneiss. However, no connection between this horizon and the Tasiussaq horizon can be established, and it cannot be traced as far as the other markers, so it has been omitted from the map in fig. 2 and is not discussed further in this paper.

On the other hand, the sequence amphibolite (lenses) - Tasiussaq augen gneiss - country gneiss - mylonitic biotite schist has been traced on foot over a large part of the Nunârssugssuaq peninsula (fig. 2). The structure it defines here is simple, consisting of open NE plunging folds (fig. 3). Where the sequence finally dips below sea level to the north-west, the Tasiussaq augen gneiss horizon can be linked rationally to the outcrop on Sătut which overlies amphibolite in the east of the island and remnants of the Marmorilik Formation in the west (fig. 3).

The marker sequence amphibolite (lenses) - Tasiussaq augen gneiss - country gneiss - mylonitic biotite schist occurs also on the peninsula south-west of Nunataq where the continuity of the sequence is even more marked and its structure very simple (fig. 3). The supracrustal character of the mylonitic biotite schist is emphasised by the common occurrence of garnet and occasional occurrence of graphite and of marble in the horizon. Locally it is ultra-mylonitic.

The marker sequence finally disappears below the level of erosion on the north side of Drygalski Halvø. A conspicuous lens of marble occurs within the mylonitic biotite schist here; this marble is quite different from the carbonate rocks found in the Archaean Ningeq supracrustals on this peninsula (Knudsen, 1983).

Compared to its wide lateral extent $\left(c .750 \mathrm{~km}^{2}\right)$, the marker sequence is thin, the separation between the base of the Tasiussaq augen gneiss and the mylonitic biotite schist varying between 170 and $400 \mathrm{~m}$. The marker horizons themselves are also thin; their thicknesses have to be exaggerated if they are to be represented at all on regional maps and text figures. 
Both marker horizons show signs of having been the site of intense movements. This is most obviously the case with the mylonitic biotite schist, as its name implies. The first stage in the development of a horizon of this kind can be seen in the lower limb of the Kigarsima nappe to the north of the Agpat sheet area (Escher \& Pulvertaft, 1976, fig. 107, section I-J), where migmatised flysch of the Nukavsak Formation has been pinched in under the overriding gneiss core of the nappe. In the Tasiussaq augen gneiss, movement has been taken up mainly in zones of intense foliation that occur both within and at the margins of the horizon. In the country gneiss both below, between and above the marker horizons there are indications of strong movements. These are either confined to $0.5-2 \mathrm{~m}$ thick zones of high strain gneiss separating ordinary migmatitic vein gneiss, or are expressed as a general stronger degree of foliation in the gneiss. The zones of very high strain usually give rise to step features which can be seen on aerial photographs.

\section{Summary and interpretation}

The main facts relevant to the theme of this paper can be summarised as follows.

The Marmorilik Formation, a marble formation deposited on an Archaean basement consisting of migmatitic gneisses, amphibolites, and a megacryst granodiorite - the Tasiussaq granodiorite, can be traced from the type area at Mârmorilik to the islands south-east of Agpat where it is reduced to a narrow isoclinal syncline and overlain by augen gneiss, the deformed equivalent of the Tasiussaq granodiorite.

At the southern end of Nunataq, $40 \mathrm{~km}$ east of Agpat, the Marmorilik Formation reappears, again underlying augen gneiss. This augen gneiss forms a layer that can be followed with almost no interruption (bar fjords) back into the Tasiussaq augen gneiss in the islands south-east of Agpat. For a large part of this stretch, and also on the peninsula south-west of Nunataq, there is another marker horizon $170-400 \mathrm{~m}$ above the Tasiussaq augen gneiss marker. This upper marker is a mylonitic biotite schist.

Both marker horizons, and also zones within the nearby country gneisses, show signs of very strong deformation.

The interpretation of the relationships and features described can only be that major ductile thrusting and stretching has brought the Tasiussaq augen gneiss over the Marmorilik Formation over an area of at least $1250 \mathrm{~km}^{2}$. The lateral displacement involved is of the order of $50 \mathrm{~km}$. The Marmorilik Formation beneath the augen gneiss marker has been reduced to a thin isoclinal syncline or completely cut out. The direction of transport of the overlying rocks is not known but might be reflected in the widespread NNW-SSE lineation in the gneisses in this area.

The mylonitic biotite schist represents another major ductile thrust and inversion. The biotite schist and remnants of marble within the horizon are believed to be correlatives of the Karrat Group. These supracrustals were used as a slip plane when the overlying gneisses moved over them.

Thus the concordant stack of layers of different gneiss types and supracrustal rocks that defines a deceptively simple structure in the south-east part of the Nunârssugssuaq peninsula and on the peninsula to the south (fig. 3), is in fact a pile of thin thrust sheets. Although all the layers are equally concordant, two - the Marmorilik Formation where it is present, and the mylonitic biotite schist - are Lower Proterozoic supracrustal horizons, while the banded 
amphibolites and various gneiss types are Archaean. Thrusting took place under conditions of amphibolite facies metamorphism. There is clear evidence in the Marmorilik Formation that metamorphism outlasted stretching and shearing of the formation.

Interleaving of basement and cover by means of recumbent folding and ductile thrusting has been known at least since Argand (1911) illustrated the relationship between Hercynian gneisses and Triassic marble and schistes lustrés in the Pennine Alps. The structures described in the present paper are, however, much thinner relative to their lateral extent than the Pennine nappes.

Ductile thrusting and isoclinal folding such as envisaged here has been inferred to be one of the causes of the layered character of the rock mass in the Archaean of the Godthåb-Fiskenæesset area, West Greenland (Bridgwater, McGregor \& Myers, 1974). In the Umanak area, however, it is possible to demonstrate that a large-scale layered metamorphic basement complex does indeed owe its character to tectonic interleaving, as the layered rock pile can be traced back into an area where simple primary relations are well preserved.

\section{Implications for the West Greenland Precambrian}

\section{Umanak area}

The outcrops of the Marmorilik Formation described in the foregoing are not the only occurrences of marble in the Umanak area. There is a thin layer of marble high up in the cliffs on the north side of Storøen (fig. 2), and a marble layer is involved in the spectacular recumbent fold seen in the cliffs of Pingingaq in the west of Drygalski Halvø (Escher \& Pulvertaft, 1976, fig. 109). Having demonstrated the complexities of basement-cover interleaving in the area, it is now not only plausible but entirely reasonable to suggest that these marble occurrences belong to the Marmorilik Formation, not least when the strong lithological similarities between all these marbles are borne in mind. The same applies to the outcrops of marble farther to the south-west on Nûgssuaq peninsula.

On Storøen and the peninsula to the east there are two conspicuous horizons of rustybrown weathering biotite-garnet-sillimanite \pm graphite schist in which there are layers of sulphide and low-grade silicate iron formation (Akugdleq supracrustals; Jørgensen, 1983). These lithologies are not known in the Archaean Ningeq supracrustals (Knudsen, 1983) but resemble highly metamorphosed parts of the Nukavsak Formation. The demonstrable cover-basement interleaving in the area lends credibility to the suggestion that the Akugdleq supracrustals belong to the supracrustal cover and may be a correlative of the Nukavsak Formation.

\section{Rinkian and Nagssugtoqidian}

The name 'Rinkian' was introduced by Escher \& Pulvertaft (1976) to distinguish a belt of Precambrian rocks in West Greenland characterised by a thick Lower Proterozoic supracrustal cover and mantled gneiss dome structures from the Nagssugtogidian with its ENE-WSW 'straight belt' trend and steep dips. Since there is some doubt about the age of both rocks and structures in the north-east of Disko Bugt, the Rinkian is not shown as extending as far south in fig. 1 as it is in Escher \& Pulvertaft's review. On the other hand it is 
obvious from descriptions of the stratigraphy, structural style and age of the Foxe fold belt in eastern Canada, in particular from the Dewar Lakes area in Baffin Island (Tippett, 1979), that the Rinkian is a continuation of the Foxe fold belt.

The area with which this paper is concerned lies at the southern margin of the Foxe-Rinkian belt (fig. 1). Mantled gneiss domes are no longer seen (the southernmost dome occurs just north of the area shown in fig. 2), and the thick Proterozoic cover is reduced to thin isoclines and tectonic slithers interleaved with the gneiss basement. Relatively low dips, recumbent folds and thrust slices characterise the structural style (Pulvertaft, 1973). Can this area tell us anything about the relation between the Rinkian and the Nagssugtoqidian? From the GGU 1:500 000 map Søndre Strømfjord - Nûgssuaq (Escher, 1971), supracrustal belts in the Nagssugtoqidian appear to be of two types: amphibolite dominated belts, and mica schist-quartzite-marble dominated belts. Kalsbeek, Taylor \& Henriksen (1984) argue that at least the latter are of lower Proterozoic age, while much, but not all, of the gneiss in the Nagssugtoqidian is Archaean. If this is so, a phase of interleaving of metasedimentary cover and basement gneiss prior to the development of the characteristic Nagssugtoqidian 'straight belt' style, is a prerequisite for the development of the Nagssugtoqidian. The present paper demonstrates that precisely this type of interleaving has taken place at the southern margin of the Foxe-Rinkian belt in Greenland. Before the area is hailed as transitional between the Foxe-Rinkian and Nagssugtoqidian belts, more detailed work is required in the intervening area between Jakobshavn and Nûgssuaq.

Acknowledgements. I would like to thank $\mathrm{F}$. Kalsbeek for encouraging me to write this paper, and my assistants H. Olsen, P. Abildgaard and A. Thorsh $ø$ j Nielsen for accompanying me cheerfully as I traced out the marker horizons.

\section{References}

Andersen, M. C. \& Pulvertaft, T. C. R. 1985: Rb-Sr whole rock 'ages' from reworked basement gneisses in the Umanak area, central West Greenland. Bull. geol. Soc. Denmark 34, 205-212.

Argand, E. 1911: Les nappes de recouvrement des Alpes occidentales. Carte structurale 1/500,000. Matériaux Carte géol. Suisse, N.S. Livraison 31.

Bridgwater, D., McGregor, V. R. \& Myers, J. S. 1974: A horizontal tectonic regime in the Archaean of Greenland and its implications for early crustal thickening. Precambrian Res. 1, 179-197.

Dawes, P. R. \& Kerr, J. W. (edit.) 1982: Nares Strait and the drift of Greenland: a conflict in plate tectonics. Meddr Grønland, Geosci. 8, 392 pp.

Escher, A. 1971: Geologisk kort over Grønland, 1:500 000, Søndre Strømfjord - Nûgssuaq. Copenhagen: Grønlands geol. Unders.

Escher, A. \& Pulvertaft, T. C. R. 1976: Rinkian mobile belt of West Greenland. In Escher, A. \& Watt, W. S. (edit.) Geology of Greenland, 105-119. Copenhagen: Geol. Surv. Greenland.

Garde, A. 1978: The Lower Proterozoic Marmorilik Formation, east of Mârmorilik, West Greenland. Meddr Grønland 200(3), 71 pp.

Garde, A. \& Pulvertaft, T. C. R. 1976: Age relations of the Precambrian Mârmorilik Marble Formation, central West Greenland. Rapp. Grønlands geol. Unders. 80, 49-53.

Henderson, G. 1969: The use of structural contour maps in the study of gneiss-metasediment relations in the Umanak area, West Greenland. Spec. Pap. geol. Ass. Can. 5, 129-142.

Henderson, G. \& Pulvertaft, T. C. R. 1967: The stratigraphy and structure of the Precambrian rocks of the Umanak area, West Greenland. Meddr dansk geol. Foren. 17, 1-20. 
Jørgensen, J. B. 1983: Geology of the islands Umanak $\emptyset$, Storøen, Akugdleq and the peninsulas Qaqugdlugssuit and Augpilagtoq in the Umanak Fjord, West Greenland. Unpublished cand. scient. thesis, Geological Institute, Univ. of Copenhagen. $167 \mathrm{pp}$.

Kalsbeek, F. 1981: The northward extent of the Archaean basement of Greenland - a review of Rb-Sr whole-rock ages. Precambrian Res. 14, 203-219.

Kalsbeek, F., Taylor, P. N. \& Henriksen, N. 1984: Age of rocks, structures and metamorphism in the Nagssugtoqidian mobile belt, West Greenland. Can. J. Earth Sci. 21, 1126-1131.

Knudsen, J. C. 1983: Geology of the area between Sermigdlip kangerdlua and Sermerdlat kangerdluat. Unpublished cand. scient. thesis, Geological Institute, Univ. of Copenhagen. 226 pp.

Myers, J. S. 1978: Formation of banded gneisses by deformation of igneous rocks. Precambrian Res. 6, 43-64.

Pulvertaft, T. C. R. 1973: Recumbent folding and flat-lying structure in the Precambrian of northern West Greenland. Phil. Trans. R. Soc. Lond. A273, 535-545.

Sibson, R. H. 1977: Fault rocks and fault mechanisms. J. geol. Soc. Lond. 133, 191-213.

Tippett, C. R. 1979: Basement-supracrustal rock relationships on the southern margin of the Foxe Fold Belt, central Baffin Island, District of Franklin. Pap. geol. Surv. Can. 79-1A, 101-105.

Institute of General Geology, University of Copenhagen, $\emptyset$ ster Voldgade 10 , $D K-1350$ Copenhagen $K$, Denmark. 